\title{
Flow Cytometric Analysis of Calcium Influx Assay in T cells
}

\author{
Sun-Hwa Lee*
}

Department of Molecular Microbiology and Immunology, University of Southern California, Keck School of Medicine, Los Angeles, USA

*For correspondence: sunhlee@dgmif.re.kr

[Abstract] Calcium influx is one of the key signaling events upon stimulation of $\mathrm{T}$ cell receptors (TCR) and plays an important role for T cell activation, proliferation, and differentiation. Phorbol myristate acetate (PMA) and calcium ionophore ionomycin are commonly utilized as stimulants in a variety of immunologic assays including $T$ cell activation. PMA is a protein kinase $C$ (PKC) activator, resulting in the activation of Ras, a small GPTase. When PMA and ionomycin are used together, TCR signaling downstream of PKC and Ras can be activated without activation of TCRtriggerd signaling events. This protocol describes the flow cytometry analysis of intracellular calcium influx in T cells stimulated with PMA and ionomycin.

\section{Materials and Reagents}

1. Jurkat T cells (ATCC, catalog number: TIB-152)

2. DMSO (Sigma-Aldrich, catalog number: 472301)

3. RPMI media 1640 (Life Technologies, Gibco ${ }^{\circledR}$, catalog number: 21875-034)

4. Fetal Bovine Serum (FBS) (Life Technologies, Gibco ${ }^{\circledR}$, catalog number: 16000044)

5. Penicillin/streptomycin (pen/strep) (Life Technologies, Gibco ${ }^{\circledR}$, catalog number: 15140122)

6. PMA (Sigma-Aldrich, catalog number: P1585) (Store at $-20^{\circ} \mathrm{C}$ )

7. Ionomycin (Sigma-Aldrich, catalog number: 10623) (Store at $-20^{\circ} \mathrm{C}$ )

8. Calcium Assay Kit (BD Biosciences, catalog number: 640176)

9. Complete RPMI media (see Recipes)

10. PMA stock solution (see Recipes)

11. Ionomycin stock solution (see Recipes)

\section{Equipment}

1. Centrifuge (Eppendorf, model: 5810R)

2. $37^{\circ} \mathrm{C} 5 \% \mathrm{CO}_{2}$ Cell culture incubator

3. Cell Counter 
4. BD Cantoll FACS machine

5. $5 \mathrm{ml}$ round-bottom FACS tube (BD Biosciences, catalog number: 352003)

\section{Software}

1. FACS DIVA software

2. FlowJo software

\section{Procedure}

3. Preparation (For 4 samples)

1. Preparation of Jurkat T cells:

a. Count cells growing exponentially $\left(1 \times 10^{6}\right.$ per assay).

b. Wash cells once with pre-warmed complete RPMI media at $200 \times g$ for 5 min.

c. Place $1 \times 10^{6}$ cells $/ 250 \mu \mathrm{l}$ of fresh complete RPMI media into a $5 \mathrm{ml}$ FACS tube.

2. Preparation of $1 x$ enhancing solution (from Calcium Assay Kit) ( $2 \mathrm{ml}$ for 4 assays):

a. Mix $200 \mu \mathrm{l}$ of $10 x$ enhancing solution with $1.8 \mathrm{ml}$ of assay buffer.

b. Keep it at room temperature.

3. Preparation of indicator (from Calcium Assay Kit):
a. Equilibrate a vial of indicator (stored at $-20^{\circ} \mathrm{C}$ ) at room temperature for $5 \mathrm{~min}$.
b. Add $100 \mu$ l of $100 \%$ DMSO.
c. Mix well by pipetting up and down multiple times.
d. Store at RT for 10 min to stabilize completely.
e. Store unused indicator in a small aliquot at $-20^{\circ} \mathrm{C}$ until use.

4. Preparation of $1 x$ loading dye:

Mix $2 \mathrm{ml}$ of $1 \mathrm{x}$ enhancing solution with $2 \mu \mathrm{l}$ of indicator prepared above.

5. Loading dye to cells:

Add $250 \mu$ of $1 x$ loading dye (prepared in step 4) into each tube containing cells.

6. Incubate tube for $1 \mathrm{~h}$ in $37^{\circ} \mathrm{C} \mathrm{CO}_{2}$ Incubator.

7. Cool down tube at RT for 20 min before analysis.

\section{FACS analysis}

1. Open the FACS DIVA software.

2. Draw a dot plot (Time is on the X-axis, and FITC is on the Y-axis).

3. Place a tube to the FACS machine.

4. Click "Record Data" for 1 min to obtain the basal level of signal.

5. Click "Stop Acquiring" and remove the tube from the FACS machine. 
6. Immediately add $1 \mu \mathrm{l}$ of stimulator [a mixture of PMA $(50 \mathrm{ng} / \mathrm{ml})$ and ionomycin $(1 \mu \mathrm{g} / \mathrm{ml})$ ].

7. Vortex briefly and place the tube back to the FACS machine.

8. Click "Record Data" for additional 3 min.

9. Click "Append" to attach acquired signal to the 1 min basal level of signal acquired in step 4.

10. Click "Stop Acquiring" to finish the assay.

11. Analyze each data with FlowJo software by choosing kinetic mode.

12. Overlay sample data on the control data to display the difference of signal between the control and sample on one Figure as shown in Figure 1.

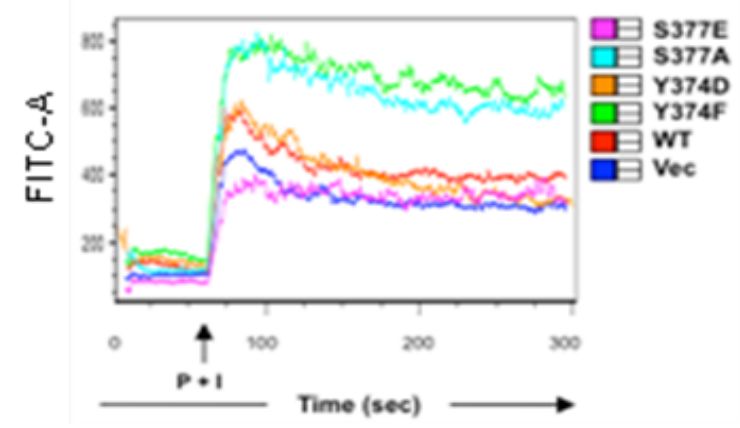

Figure 1. Intracellular $\mathrm{Ca}^{2+}$ influx in IKKY/NEMO-deficient Jurkat $\mathrm{T}$ cells stably complemented with Ha-tagged IKKYINEMO WT or mutants (S377E, S377A, Y374D, Y374F). Cells were loaded with $\mathrm{Ca}^{2+}$ indicator for $1 \mathrm{~h}$ at $37^{\circ} \mathrm{C}$. Intracellular $\mathrm{Ca}^{2+}$ influx upon PMA and ionomycin $(\mathrm{P}+\mathrm{I})$ treatment was monitored for 5 min by flow cytometry analysis. Vec stands for vector control.

\section{$\underline{\text { Recipes }}$}

1. Complete RPMI media

RPMI containing 10\% FBS and 1\% penicillin/streptomycin

2. PMA stock solution

$50 \mathrm{ng} / \mathrm{ml}$ DMSO

3. Ionomycin stock solution

$1 \mu \mathrm{g} / \mathrm{ml}$ DMSO

\section{Acknowledgments}

This protocol is adapted from Lee et al. (2012). 


\section{References}

1. Lee, S. H., Toth, Z., Wong, L. Y., Brulois, K., Nguyen, J., Lee, J. Y., Zandi, E. and Jung, J. U. (2012). Novel Phosphorylations of IKKgamma/NEMO. MBio 3(6): e00411-00412. 